\title{
SAKRALINĖS ARCHITEKTŪROS SIMBOLIZMAS H. U. VON BALTHASARO IR K. RAHNERIO TEOLOGIJOJE
}

\author{
Linas KRŪGELIS \\ Dizaino katedra, Architektūros fakultetas, Vilniaus Gedimino technikos universitetas, \\ Sauletekio al. 11, LT-2040 Vilnius, Lietuva \\ El.paštaslinnarri@yahoo.com
}

Iteikta 201409 22; priimta 20140930

\begin{abstract}
Santrauka. Sakralinė architektūra, būdama glaudžiai susieta su konkrečia religija, visuomet buvo gaubiama paslaptingumo ir mįslingumo šydu. Sakraliniai simboliai bažnyčių architektūroje yra plati ir nedaug ištirta sritis. Menotyroje simbolis dažnai suvokiamas kaip regimas, asociatyvus vaizdinys, turintis savo prasmę. Sakralinès architektūros simbolizme XX a. ịvyko nemažai reikšmingų pokyčių. Kyla klausimų, kodèl naujosios minimalizmo srovei priskirtinos bažnyčios stokoja ikonografinių regimųjų religinių simbolių ir ženklų. Ar tikrai dèl šių elementų stokos kaltas postmodernus sekuliarusis menas?

Straipsnyje siekiama tarpdalykinio pobūdžio tyrimu aptarti galimą teologinių srovių įtaką šiuolaikinei bažnyčių architektūrai. Lyginama, kaip kito bažnyčios kaip kulto pastato samprata po Antrojo visuotinio Vatikano Bažnyčios susirinkimo. Nagrinèjami dèl šių procesų sąveikos atsiradę architektūros pavyzdžiai.
\end{abstract}

Reikšminiai žodžiai: simbolis, sakralumas, architektūra, bažnyčia, teologija, minimalizmas.

\section{Ivadas}

Architektūra, kaip viena iš svarbiausių žmogaus kūrybinių galių apraiškų, visais laikais buvo gaubiama mịslingumo, paslèptų prasmių, emocinès ịtaigos skraiste. Žvelgdami ị praeiteis architektūros istorinę perspektyvą, regime, jog subtiliųjų architektūros meninių prasmių fone dominuoja sakralinių pastatų kontūrai. Mūsų geografinëje ir kultūrinejje plotmëje architektūros meninio, mistinio simbolizmo plotmèms ryškiausiai atstovauja katalikiškų sakralinių pastatų kūrimo tradicija. Šios tradicijos gijos siekia antikos laikus, kur buvo suformuotas pagrindas Europos architektūros raidai. Tačiau tradicija yra tik vienas iš atramos taškų architektūros raidoje, nors kartais ir suvokiamas kaip ribojantis ar pažangą varžantis veiksnys. Tradicijos ir inovacijų konfliktas yra neišvengiamas, bet tik iš šių demenų santykio mes galime įvertinti architektūroje vykstančius pokyčius.

Šiuolaikiniuose menotyros tekstuose tarsi jau tapo populiaru kritiškai vertinti šiuolaikinių katalikiškų sakralinių pastatų architektūrą arba subtiliąsias šių pastatų meninès formos reikšmes. Kaip yra rašęs
Camilian Demetrescu, „didžioji dalis tyrimų, skirtų tyrinèti krikščioniškoms šventykloms, sakraliniams simboliams skiria per mažai demesio arba jo neskiria visiškai. Tokie tyrinejjimai dažnai apsiriboja tik bažnyčios pastato funkcinių, estetinių, medžiaginių savybių aprašymu“ (Demetrescu 2000). Pažymètina ir tai, kad šiuolaikiniai katalikų bažnyčiu pastatai dažnai kritikuojami dèl pernelyg išreikšto modernumo ir dèl sakralinių simbolių ir jų prasmių stokos. Reiškiamą kritiką galima išskirti ị dvi esmines, tarpusavyje sunkiai atsiejamas kryptis - meninę ir teologinę. Meniniai bažnyčios pastato sprendiniai yra tiesiogiai susieti su teologine mintimi, bažnyčios pastoracine misija. C. Demetrescu publikacijoje „Simboliai sakralineje architektūroje ir ikonografijoje" (angl. Symbols in Sacred Architecture and Iconography), apibendrindamas savo mintis apie šiuolaikinès architektūros universalių simbolių naudojimą, teigé, „kad žinių sklaidos šia tema stinga ne tik mokant architektūros, bet ir rengiant dvasininkus teologiškai“. Todèl, anot jo, nesunku įsivaizduoti šio dvejopo ignoravimo pasekmes šiuolaikinei 
sakralinei architektūrai. „Esame tiesiog epideminio architektūros ir ikonografijos hibridizavimo liudininkais dèl simbolių kultūros stokos ir prasto statytojų ir klientų skonio" (Demetrescu 2000). Sakralinis menas nuo seniausių laikų sietinas su tikejimo tiesų perteikimu, todèl ir šio pobūdžio mene greta meninès formos kriterijų regime ir atitikties skelbiamoms tikejimo tiesoms būtinybę. Menotyroje tyrinèjant šiuolaikinę sakralinę architektūrą, jos simbolizmą, retai kada atsižvelgiama ị religinès minties raidą nagrinejjamu laikotarpiu, o tai yra tiesiogiai susiję ir su sakralinès architektūros raida.

Šio straipsnio tikslas yra palyginti teologinès minties, orientuotos ị liturgijos šventimą, raidą su meninių formų kaita sakralinèje architektūroje. Straipsnyje aptariami žymiausių XX a. Katalikų Bažnyčios teologų Hanso Urso von Balthasaro ir Karlo Rahnerio požiūriai ì sakralumo sampratą ir ją lemianti sakralinių simbolių iprasminimo tradicijos kaita. Pasitelkiant lyginamąji metodą yra gretinamos religinès minties ir architektūros raidos sintezès apraiškos. Istoriniu aprašomuoju metodu apžvelgiami kertiniai istoriniai duomenys, formuojantys šiame straipsnyje atliekamo tyrimo pagrindą. Taikant hermeneutinį metodą, interpretuojamos simbolių apraiškos ir reikšmès bažnyčių architektūroje.

\section{Architektūrinis bažnyčios simbolizmas pagal H. U. von Balthasaro teologinę doktriną}

Nèra nauja teigti, kad bažnyčios pastato kūrimas neapsiriboja vien tik estetine ir technologine problematika, tačiau yra glaudžiai susietas su Bažnyčios pastoracine misija ir vizija, kuri abstrakčiai nurodo, apibrèžia kulto pastato sampratą. Lietuvoje šiuo metu stinga literatūros, kurioje, remiantis religinès simbolikos perspektyva, būtų nagrinejjama ir pristatoma šiuolaikinès bažnyčios, kaip kulto pastato, paradigmos kaita $\mathrm{XX}$ a. Perfrazuojant lenkų kilmès amerikiečių teologo R. Vosko mintis, šiuolaikinio bažnyčios pastato transcendencijos supratimas prasideda nuo pastato prasmès giluminio supratimo per šiuolaikinès teologijos prizmę. R. Vosko savo knygoje „God's House is Our House" glaustai aptaria dvi, jo teigimu, ikonines teologijos sroves - Karlo Rahnerio ir Hanso Urso von Balthasaro. Šios srovès nulemė XX-XXI a. bažnyčios, kaip transcendentalaus sakralinio pastato, sampratos kaitą. Todèl pravartu plačiau ir kontekstualiau aptarti šių dviejų teologijos korifejų ịtaką architektūros ir sakralinio simbolizmo raidai.

H. U. von Balthasaras, gimęs Liucerne (Šveicarija, 1905 m.), buvo katalikų kunigas, jèzuitas. Dar prieš teologijos studijas jis pasižymejo kaip talentingas pianistas ir Mocarto kūrybos gerbèjas. Šiandien Balthasaras lai- komas vienu iš pagrindinių XX a. Katalikų Bažnyčios teologų, dariusių ịtaką Vatikano Antrojo visuotinio Bažnyčios susirinkimo nulemtų pokyčių krypčiai. Kartu su bendraminčiu Josephu Ratzingeriu (vèliau pop. Benediktas XVI) Balthasaras buvo labiau priskiriamas prie katalikiškosios tradicijos gaivinimo, atnaujinimo šalininkų nei prie liberaliųjų reformatorių. Jo pasaulèžiūrai didelę reikšmę turèjo Ignaco Lojolos mistiniai tekstai bei Tomo Akviniečio propaguota universalaus grožio samprata. Kaip rašè Randy's Stice'as, T. Akviniečio teologijoje grožis apibrēžiamas trimis sąvokomis: integritas (vientisumas, užbaigtumas), consonantia (proporcija), claritas (tyrumas, ontologinis grynumas) (Stice 2012). O ir Balthasaro teologijos pasaulèvaizdis aprašomas naudojantis panašiais estetiniais pavyzdžiais. Jo ịsitikinimu, Dievo apreiškimas visada yra stebinantis ir netikètas, jo niekas negali nei kontroliuoti, nei nuspèti. „Dievas niekada negali būti visiškai užčiuoptas ir visada išliks transcendentalus žmogiškajai patirčiai. <...> Šiame ikoniškame pasaulyje Dievas yra grožis, todèl neturètų būti pajaustas arba pastebėtas stebètojo tam, kad būtų ịvardintas kaip objektyvus grožis“" (Vosko 2006). R. Vosko nuomone, H. U. von Balthasaras bažnytinius sakramentus laiko tarsi keliavimo priemone rojaus link ir pilnutiniu Dievo patyrimu (ten pat). Anot H. U. von Balthasaro, Eucharistijos liturgija, bažnytinè muzika, liturginiai tekstai, dailè ir architektūra, panaudojami bendram transcendentiniam tikslui, turi būti gražūs, tyri, nesutepti tam, kad deramai tarnautų lyg kelias pas Aukščiausiąji (Vosko 2006). Todèl Balthasaro transcendencijos supratimą priimta laikyti kaip „vertikalųjit“ Dievo pažinimą.

Balthasaro požiūris ị svarbiausius katalikiškosios minties aspektus dažnai tapatinamas su labiau tradicionalistiniu požiūriu ị bažnyčią kaip ị sakralinę erdvę. Neatsitiktinai Balthasaro teologiją raiškiai atspindi linijine, simetriška arba disimetriška bažnyčios išplanavimo struktūra, turinti aiškią vidaus erdvių ir daiktinių elementų semantinę hierarchiją. Bažnyčios, kaip sakralinès erdvès, substancialioji kokybè nusakoma panašiais kriterijais, kaip ir Senojo Testamento tradicijoje minimos žydų šventyklos, kuriose dominuoja regimoji architektūros, dailès ir religinių ritualų kokybe. Neveltui žymus Balthasaro teologijos tyrinètojas Aidanas Nicholsas, charakterizuodamas Balthasaro katalikiškosios teologijos kryptị, ją apibūdina trimis žodžiais - gražu, gera ir tikra (Nichols 2011). Pasak šio autoriaus, Balthasaras buvo tvirtai ịsitikinęs, jog transcendenciją žmogus gali pajusti ir pagrindinemis savo juslèmis - regejjimu, lytëjimu, uosle, skoniu. Žinoma, jei tik šioms juslèms bus suteiktas tinkamas impulsas, kuri gali sužadinti vaizdiniai ir simboliai. 
Architektūroje šie principai galioja ir bažnyčios erdvės sakralumui, jo pajautai. Todèl šios teologinès srovès šviesoje bažnyčios vidaus erdvè suprantama kaip aukštesniųjų, antgamtinių realybės formų reprezentavimo vieta. Idomu tai, kad tiek dvasininko, tiek bažnyčios lanky tojo vaidmenys Balthasaro teologijoje yra asociatyviai siejami su architektūrinių erdvių ir daiktinių elementu tarpusavio hierarchija. 1 pav. pateiktoje schemoje pavaizduotos simbolinès asociacijos tarp dieviškojo pasaulio ir regimosios bažnytinès erdvès. Charaketrizuodamas bažnyčios simbolines erdvės sąsajas su transcendencija, Balthasaras, pasak R. Vosko, išskiria tris lygmenis, kuriuos tarpusavyje gretina. Pradiniu tašku šioje grandineje yra erdvè dangus, dangaus vartai, žemé, visa tai sugretinama su gyvuoju pradu - Dievu, dvasininkija, žmonèmis. Architektūriniu pavidalu visa tai perteikiama skirtingomis sakralinemis erdvemis - tabernakulio, presbiterijos, pagrindinès navos (1 pav.).

\begin{tabular}{|c|c|c|c|}
\hline Rojus & Dievas & Tabernakulis \\
\hline Žemej & Dvasininkai vartai & Presbiterija, \\
\hline altorius
\end{tabular}

1 pav. Bažnyčios pastato prasminè struktūra pagal U. H. von Balthasaro teologiją (Vosko 2006)

Fig. 1. Symbolic structure of the church building according to the theory by U. H. von Balthasar (Vosko 2006)

Iš pateiktos schemos matyti, kad U. H. von Balthasaro teologijoje bažnyčia suvokiama simbolinès vertikalès principu, pagal kintantị sakralumo lygmenį ir jo metafizinę prasmę. Čia esama panašumų ir su Mircea Eliade filosofiniu modeliu - axis mundi. Šios schemos, o kartu ir Balthasaro teologinio mokymo, ištakas galima ¡̇žvelgti bažnyčiose, pastatytose po Tridento visuotinio bažnyčios susirinkimo $(1563 \mathrm{~m}$.). Tokia hierarchizuota šventovès struktūra ilgus šimtmečius buvo išreiškiama sąvoka - Domus Dei (lot. Dievo namai), o liturgijos centre išstatomas Dievo buveinę simbolizuojantis tabernakulis. Tokiose bažnyčiose buvo stengtasi perteikti amžinojo gyvenimo tobulybę. Tačiau tradiciškai krikščioniškąja šventykla labiausiai buvo siekiama atspindèti Kristaus kūną, todèl tam tikros pastato dalys asocijavosi su Kristaus kūno dalimis (Demetrescu 2000). Kitaip tariant, regimieji sakralumo simboliai, ju estetinè, dangiškumą reprezentuojanti kokybè yra esmingai svarbūs $\mathrm{XX}$ a. Balthasaro teologijoje.

Transcendencijos ir sakralumo samprata, kuria gvildeno U. H. von Balthasaras, būdinga ir kitiems šio laikotarpio sakralinès architektūros ir sakralinio simbolizmo tyrinètojams. Pavyzdžiui, krikščionių teologas D. Foy Christophersonas rašè, kad sakralinè erdvè turi pirmapradị ryši su natūraliu grožiu, kuris regimas iš Dievo kūriniu gamtoje. Todèl bet kokie daiktai, naudojami Dievui garbinti, turi pasižymèti natūraliu savo grožiu, turi būti vengiama imitacijų iš menkaverčių medžiagų (Christopherson 2004). Toliau šis autorius mini, kad bet kokia erdvè, ar ji būtų sakralinè, ar sekuliari, veikia žmogu per specialią simbolių kalbą. Pačių simbolių išraiškos formos gali būti įvairios, jos gali reikštis įvairiais pavidalais: per šviesą, spalvą, garsą, įvairių tipų ženklus, medžiagą (vanduo, taurieji metalai). Šių elementų tinkamas pritaikymas, harmoningas suderinimas suteikia bažnytinei erdvei sakralumo ir transcendentalumo savybių. To mes negalime pamatuoti empiriškai, tačiau kaip sakralinès erdvès stebètojai ir dalyviai galime įsitikinti metafizinių substancijų reikšme harmonizuojant sakralinę erdvę. Ryšys tarp regimosios simbolio išraiškos ir neregimosios prasmès akcentuojamas ir kitų autorių tekstuose. Pasak žymaus sakralinių simbolių tyrinètojo Juano Eduardo Cirloto, žmogaus regimoji aplinka, o ypač gamta, buvo ankstyvųjų žmonių ỉkvepejai kurti meną, o kartu ir simbolius (Cirlot 2002). Arba kaip Šv. Paulius yra teigęs apie regimybès ir neregimybès ryšti, - Per visibilia ad invisibilia. „Tai reikštų, kad žmogus dar nuo istorijos aušros intuityviai siekẻ neregimybę vaizduoti regimu pavidalu, jausdamas šių substancijų tarpusavio ryši “" (ten pat). Žymaus XX a. filosofo Carlo Gustavo Jungo ịsitikinimu, „žodis arba vaizdinys tampa simboliu, kai jis reiškia kažką daugiau nei akivaizdžioji jo reikšmè. Simbolis turi platesnę pasąmoninę reikšmę, kuri niekada nèra tiksliai ir iki galo paaiškinama. <...> Kai protas tyrinejja simbolí, jis vedamas link idejų, kurių priežastingumą sunku užčiuopti“" (Jung 1968). Iš viso to matome, kad sakralinių simbolių reikšmè žmogaus aplinkoje, be abejo, ir architektūroje, yra pamatinė sąlyga kuriant sakralinę erdvę. Tačiau simbolių ịprasminimas architektūroje gali reikštis ịvairiais, o laikui bėgant net ir kintančiais pavidalais. Daugelis išvardintų simbolių kalbos architektūroje pasireiškimo principų gali būti susieti su H. U. von Balthasaro propaguota universalaus grožio, estetinio tobulumo sakralineje erdveje svarba.

Šių dienų sakralinèje architektūroje Balthasaro požiūris ị erdvès ir regimųjų bažnytinių simbolių sakralumą dažniausiai fragmentiškai perteikiamas kai kuriose tradicionalistinio pobūdžio bažnyčiose. Joms būdingas regimųjų ženklų ir simbolių eksponavimas (kartais ir pernelyg tiesmukas), pasireiškiantis ikonografinio pobūdžio dailès kūriniais, tradiciškai aiškiai atskirta presbiterijos zona, o pagrindinis 
altorius ịkomponuotas vienoje centrineje simetrijos ašyje kartu su pagrindiniu iejjimu, tabernakulis kai kuriais atvejais taip pat komponuojamas šioje ašyje. Tokių šventovių meninejje raiškoje simbolių kalba ryškiausiai perteikiama dailès kūriniais, o pastato tūryje stengiamasi pasitelkti kompozicines harmonizavimo priemones, ypač apimtinių formų proporcijų darną. Siejant Balthasaro teologiją su šių dienų sakraline architektūra, ko gero, tiksliausiai ši ryšs̆ apibrežti kaip tiesiogiai proporcingą ryšiui su tradicija. Daugeliui šiuolaikinių architektų archetipinis bažnyčių ivvaizdis glaudžiai susijęs su didingų praeities šventovių pavyzdžiais, neretas kūrèjas kurdamas šių dienų architektūrą semiasi patirties iš tradicijos. Tokia tendencija ypač ryški ir Lietuvoje, kai 1990 m., atgavus nepriklausomybę, vèl pradèta statyti bažnyčias, didelio visuomenès bei dvasininkijos palaikymo sulaukè glaudų ryši su tradicija išlaikiusi naujųjų bažnyčių architektūra. Tikètina, kad tam ịtakos turẻjo ir gausus Lietuvos sakralinès architektūros paveldas.

\section{XX-XXI a. sakralinė architektūra ir K. Rahnerio teologijos ịtaka}

XX-XXI a. Katalikų Bažnyčios istorijoje vienu iš reikšmingiausių įvykių yra laikomas Antrasis Vatikano susirinkimas 1963 m. Pokyčiai sakralinès architektūros tradicijoje paprastai yra siejami su šio susirinkimo metu priimtų naujų taisyklių ir normų ittvirtinimu. Neretai ir dèl nesėkmingų naujųjų bažnyčių projektų pasigirsta kaltinimai naujajai dogminei konstitucijai - Sacro Sanctum Concilium, priimtai šio visuotinio Bažnyčios susirinkimo metu. Tačiau architektūros tyrinèjimuose paprastai nèra kalbama apie gilesnius priežastinius ryškius, nulemusius pokyčius liturgijoje ir sakralinio meno (o kartu ir sakralinių simbolių raiškos) tradicijoje. Vienu iš tokių veiksnių galima laikyti Karl Rahner teologijos įtaką. Jo darbai turèjo įtakos Antrojo Vatikano susirinkimo veiklai. K. Rahneris pats buvo vienas iš Susirinkimo rengejjų, ekspertų. Issigilinus ị K. Rahnerio katalikiškąją pasaulèžiūrą, galima suprasti kai kurias šiuolaikinių bažnyčių minimalistinio stiliaus ir simbolių kalbos tendencijas.

K. Rahnerio teologinė krikščioniškos transcendencijos vizija remiasi Dievo, kuris, tapęs žmogumi (inkarnacija), pakeičia, transformuoja žmoniją. Pasak R. Vosko, K. Rahneris Dievą supranta kaip beribį laiko ir erdvès požiūriu, jis įsitikinęs, kad Dievą galima patirti laisvai ir asmeniškai per giluminę realybès dimensiją (ten pat). Tačiau lygiai taip pat K. Rahneriui Dievas yra ir didysis slëpinys, imanentiškas, egzistuojantis čia ir dabar, tačiau kiekvienas, kuris susitinka Dievą, yra evoliucionuojantis, augantis ir susitraukiantis tarsi visata. Pagrindiniu Dievo pažinimo principu jis laiko tikinčiųjų sambūrị eucharistinejje liturgijoje, kai pasitelkiant giesmes, maldas, judesius, aplink supančias spalvas ir šviesą sukuriamas tikèjimo bendrystès jausmas (ten pat). Malda tokiu atveju sutelkiama ne į Dievą, kaip atskirą esybę, bet ị jo buvimą tikinčiųjų sambūryje. Toks kontempliavimo principas dažnai vadinamas „horizontaliuoju“ (2 pav.).

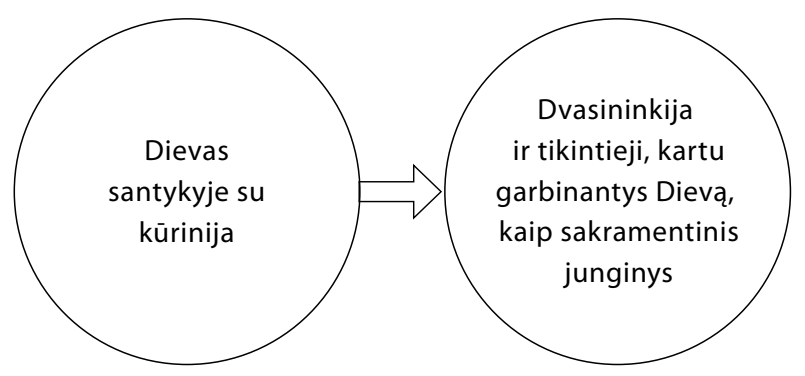

2 pav. Bažnyčios plano, remiantis K. Rahnerio teologija, prasminè schema (Vosko 2006)

Fig. 2. Symbolic meaning of the church plan according to theological theories by K. Rahner (Vosko 2006)

H. U. von Balthasaro teologinę mąstymo krypti galima reprezentuoti linijine bažnyčios pastato struktūra, o Rahnerio požiūrị i liturgiją atspindi centralizuoto arba laisvojo planavimo bažnyčia. Tokio tipo bažnyčiose kuriama kitokia sakralumo pajauta, čia siekiama sužadinti kolektyvinio maldingumo, tikèjimo bendrystès atmosferą. Visa bažnyčios vidaus erdvè orientuota aplink liturgijos vyksmą ir skatina tikinčiuosius joje dalyvauti, taip igyvendinama pagrindinè antrojo Vatikano susirinkimo metu ittvirtinta liturgijos šventimo koncepcija. Tokių bažnyčių interjeruose vengiama ikonografinių simbolių arba jie naudojami ypač saikingai. Taip siekiama, kad lankytojai nebūtų blaškomi iliustratyviais vaizdiniais, bet verčiau telktųsi bendruomeninei maldai.

Panašiai kaip Rahneris simbolius suvokè teologijoje, taip jų svarba atsispindi ir kai kurių sakralinès architektūros tyrèjų tekstuose. Juose simbolis akcentuojamas nebe kaip vaizdinys - tarpininkas tarp sacrum ir profanum, bet labiau kaip simbolinė erdvių, formų, ribų sistema, tampanti sakraliné dèl ị kontempliatyvumą orientuotos atmosferos erdveje. Šiam tikslui pasitelkiama geometrinių formų simbolika, medžiagų autentiškumas, šviesos, spalvų bei garsų sąveika.

Sukurti erdvę, kuri žadintų sakralumo, transcendencijos pajautą, anot amerikiečių architekto Stepheno Shloederio, yra didžiausias iššūkis šiuolaikiniam architektui. „Žmogus - tai kūnas ir siela, turintys laikinąją ir amžinąją dimensijas, todèl ir bažnyčios, kurias mes 
statome, turi tai perteikti“ (Schloeder 1998). Remiantis cituotu autoriumi, materijos ir dvasios skirtumai yra pernelyg dideli. Pasak jo, daugelis Vakarų mąstytojų šiandien dažnai klysta, kai bando neigti dvasingumo egzistavimą arba neigti galimybę, kad metafizinès substancijos nèra atvaizduojamos pagal ịprastus objektyvius mokslo principus (ten pat). Minètas autorius pateikia biblinį motyvą, kuris nurodo pirmapradę transcendentinę krikščionybès esmę. Teiginys „Ir Žodis tapo kūnu (Jn 1:14)"rodo konkretų transcendencijos transformavimosi į materiją vyksmą. Šiuo atveju S. Schloederis, panašiai kaip ir K. Rahneris, simbolį regi ne kaip išorinę nuorodą, bet kaip reiškinị, kuris geba būti transformuotas ị sakralinị, transcendentinị. Tokiu atveju net ir ištartas žodis (malda) gali paversti tam tikrą apibrèžtą erdvę sakraline. O erdvès architektūrinis pavidalas, kai jam suteikiama darni geometrine formų ir proporcijų visuma, geba sustiprinti erdvès sakralumo pajautą. Panašaus požiūrio laikosi ir žymus JAV architektas, holistinio dizaino propaguotojas Anthony Lawloras. Jo teigimu, erdvès sakralumas nèra vien tik kulto pastatų savybè, sakralumą galima sukurti bet kokiai fiziškai suformuotai erdvei, jei tik sugebèsime jai suteikti atitinkamai gilią prasmę (Lawlor 1994). Čia pat A. Lawloras pateikia reikšmingą Josepho Campbello poziciją apie sakralinès erdvès sampratą. J. Campbello isitikinimu, „sakralinè erdve - tai tokia erdvé, kurioje atsiskleidžia transcendencijos pojūtis $<$...>. Kai įžengiama ị tokią erdvę, aplink viskas yra simboliška, o visas pasaulis tampa mitologizuotas. <...> Tokioje erdveje viskas byloja apie dvasios pakilimą" (Lawlor 1994). Douglas Hoffmanas knygoje „Sakralumo beieškant šiuolaikinèje religinèje architektūroje" (angl. Seeking the Sacred in Contemporary Religious Architecture) kalbėdamas apie sakralumo pajautą erdveje, remiasi Rudolfo Otto mintimi, kad „erdvess sakralumo pajautos [žmoguje] nę̨manoma išmokyti, ją galima tik pažadinti mintimi, kad viskas, kas ateina „iš dvasios“, privalo būti pažadinta" (Hoffman 2010). Toliau D. Hoffmanas dar prideda, kad ,architektūra, kaip statiško būvio objektas, negali tiesiogiai (per se) mokyti, tačiau gali stebètojui suteikti nuorodas pažadintam sąmoningumui“ (ten pat).

Nuorodomis $\mathfrak{i}$ transcendenciją, kurias mini Hoffmanas, architektūroje gali būti ir geometrinès formos, kurios dar nuo ankstyvụjų civilizacijų laikų siejamos su tobulumu, tvarka ir harmonija. Ilgainiui tam tikros geometrinès formos igavo tam tikras simbolines prasmes. Antikos laikais apie geometrinių formų universalų simbolizmą rašè Platonas, suformulavęs savo penkių masyvų teoriją. Pitagorui geometrija buvo ne tik priemonè suvokti aplinkai, bet ir kertinis raktas ị Visatos paslapčių (ezoterinių ir egzoterinių) pažinimą.
Šių dienų menotyros tekstuose apie geometrinių formų simbolines reikšmes yra rašęs $C$. Demetrescu. Jo teigimu, „apskritimas krikščioniškoje simbolikoje reiškia dieviškumą, dvasinị pasaulị, šventumą. Kvadrato simbolinė reikšmè yra kosmosas, materija, žemiškasis būvis" (Demetrescu 2000). Kvadratas ịbrèžtas ị apskritimo vidų simbolizuoja dvasios virsmą ì materiją, Dievo ịsikūnijimą i žmogaus kūną. Šie simboliai kartu pasitaiko dar Bizantijos laikų bažnyčiose, kur kubo formos šventovè viršuje turedavo įrengtą apskritimo formos skliautą, reiškiantị Dievo viršenybę prieš žmogų ir dvasios viršenybę prieš materialumą.

Čia paminètų tyrinètojų požiūris ị sakralinę erdvę bei jos simbolizmą turi glaudų ryšių su K. Rahnerio formuojama bažnyčios, kaip bendruomenès sambūrio ir maldos erdvès, samprata. Erdve ir joje tarpstantys simboliai veikia ne per vaizdinit, bet per savo vaizdinę išraišką ir per sandarą - morfologiją. Lygiai taip ir bažnytinè liturgija, Rahnerio įsitikinimu, yra veiksni ne tada, kai yra stebima, bet kai joje dalyvaujama. Todèl čia galima ižvelgti gana ryškią takoskyrą tarp Rahnerio sakralinès bažnyčios erdvès sampratos ir Balthasaro ìsitikinimų. Ryškių skirtumų galima pastebèti ir architektūriniuose sprendiniuose. Anksčiau aptarto H. U. von Balthasaro teologijoje mateme dominuojant tradicionalizmą ir naujas jos raiškos formas, o K. Rahnerio teologinès idejos sèkmingai tarpsta šiuolaikinèse minimalizmo stiliaus bažnyčiose, nors šių tendencijų ištakos regimos dar gerokai anksčiau, pvz., Le Corbusier suprojektuotose šventovèse ir pan.

Kaip vieną iš charakteringiausių tokio pobūdžio šiuolaikinių pavyzdžių galima paminèti architekto Massimiliano Fuksas suprojektuotą bažnyčią Italijoje, Folinjo mieste (2009 m., 3 pav.). Čia architektas, igyvendindamas naująją katalikiškųjų mišių liturgijos sampratą, suprojektavo kubo formos bažnyčios pastatą. Architektūrinès interjero erdvès leitmotyvas - erdvèje kabanti kvadratine skliauto stilizacija. Šiuo erdviniu elementu architektas presbiteriją ir tikinčiųjų zoną suprojektuoja į vientisą erdvę. Tai raiškiai perteikia bendruomeninio dalyvavimo liturgijoje idejąa, itvirtintą po Vatikano Antrojo susirinkimo. Kartu čia įžvelgiami ir jau aprašyti K. Rahnerio teologijos principai, ̇ pirmą planą iškeliantys Dievo buvimą bendruomeneje. Sakralinių simbolių raiška šioje šventovejje subtili, dominuoja kubo kube motyvas, veikiausiai bent iš dalies atkartojantis Didžiosios Jeruzalès šventyklos ir ją supančio kiemo prototipą. O efektingas natūralios šviesos srautų modeliavimas pastato erdveje byloja apie šviesos, kaip universalios substancijos tiek fizine, tiek ir metafizine prasme, svarbą krikščionybeje. Kubas krikščioniškoje kultūroje yra dažnai pasitaikantis simbolis, kuris perteikia materijos, žmogiškojo kūno sam- 

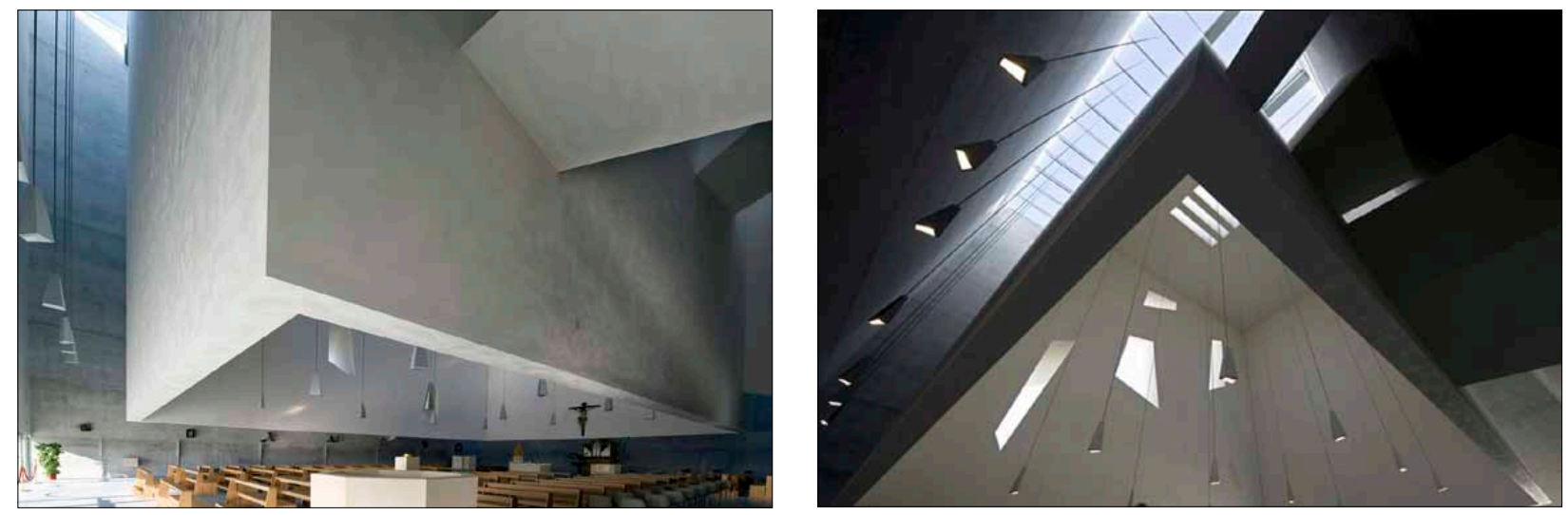

3 pav. Chiesa Di Foligno, Italija (archit. M. Fuksas ir D. Fuksas, 2009 m.)

Fig. 3. Chiesa Di Foligno, Italy (architects M. Fuksas, D. Fuksas, 2009)
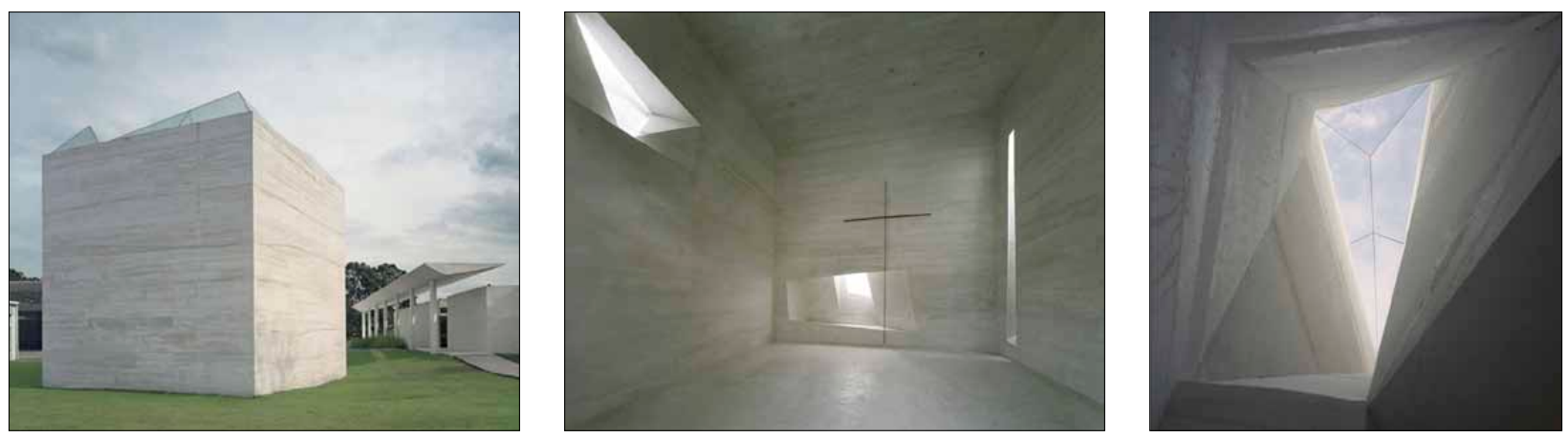

4 pav. Šventojo Rožančiaus bažnyčia St. Amant mieste, JAV (archit. Trahan Architects, 2005 m.)

Fig. 4. Holy Rosary Church in St. Amant, USA (Trahan Architects, 2005)

pratą. Kartu čia galima įžvelgti paraleles tarp Kristaus kaip Bažnyčios kertinio akmens simbolio ir teologinès doktrinos apie Dievo ịsikūnijimą įtvirtinimo. Biblijoje kubas sietinas ir su Naujosios Jeruzalès vizija, aprašyta Apreiškimo knygoje.

Panašią architektūrinę kalbą pasirinko ir architektų kolektyvas „Trahan Architects“ iš Jungtinių Amerikos Valstijų, kai kūrè Šventojo Rožančiaus bažnyčią (4 pav.) St. Amant mieste. Šie architektai sukū rè beveik akliną kubo formos tūrị, tik keletas bažnyčios interjere įstrižai sienas perveriančių nišų yra kaip švieslangiai. Estetiniu požiūriu sterili erdvè ir keletas vaiskios šviesos pluoštų sukuria ramybès ir atsiribojimo nuo išorès pojūtị. Kaip ir prieš tai aptartu atveju, čia architektai naudojo kubo formą, kaip simbolinę prasmę turinčią geometrinę formą, šị îspūdị dar sustiprindami monumentalia konstrukcine medžiaga. Krikščioniškąją koplyčios paskirtị išduoda interjero sienoje įtvirtintas kryžiaus ženklas. Ši koplyčia rodo ir atgimstančią privačių šeimos koplyčiu kūrimo tendenciją, tai nebe pirmas tokio pobūdžio sakralinès paskirties statinys šiuolaikinèje architektūros gamoje.
K. Rahnerio teologijos atspindžių galima įžvelgti ir architekto Peter Zumthor suprojektuotoje Bruder Klaus koplyčioje (2007 m., 5 pav.). Sakralumo pajautą architektas kūrè pasitelkdamas mistišką šviesos ir rupios plastinès išraiškos interjero sienų žaismą. Vertikaliai link šviesos srauto siaurejjanti erdve kuria meditatyvumo, mistiškumo atmosferą. Eksterjero tūrinè plastika radikaliai priešinga - griežtos trapecinio plano formos bokštas tarsi skulptūrinè stela iškyla virš horizonto. Galima numanyti, kad P. Zumthoras pastato išorei sieke sukurti archajiško megalito i̇spūdi, galbūt galima čia įžvelgti ir tam tikrų paralelių su kino virtuozo Stanley Kubriko fantastinio kino juosta „2001: kosminè odisèja“ (1968 m.), kur gausiai mistinių simbolių prisodrintame filme vaizduojamas ankstyvosios žmonijos susidūrimas su nežemiškais monolitais. Pastato architektūra skatina sakralumo pajautą, kurią būtų galima apibūdinti kaip meditatyvinę, tiksliau tariant, erdvès sakralumo pojūtis nèra susietas su pavieniais simboliais, bet suvokiamas iš bendros tūrinès erdvinès visumos. Tokia erdve nesistengia sakralumo iliustruoti, bet padeda ji išgyventi individualiai. 

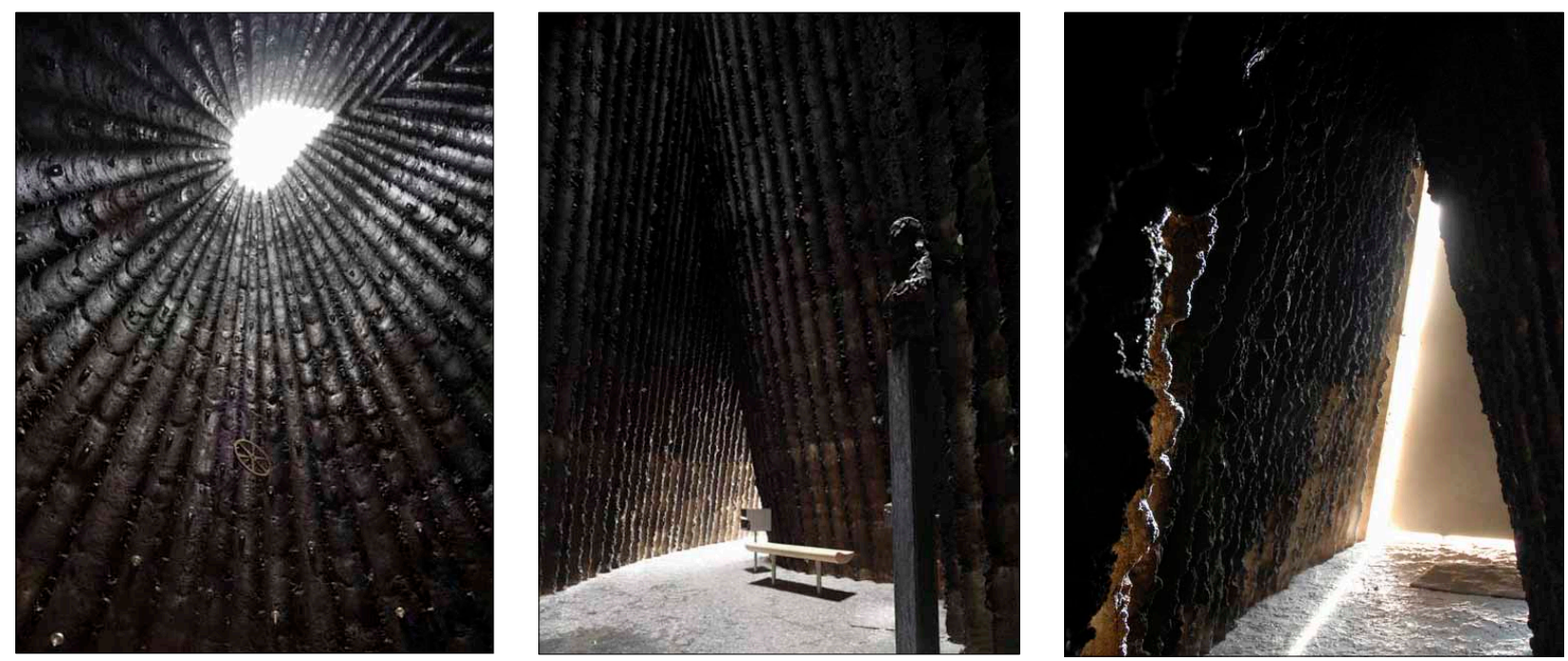

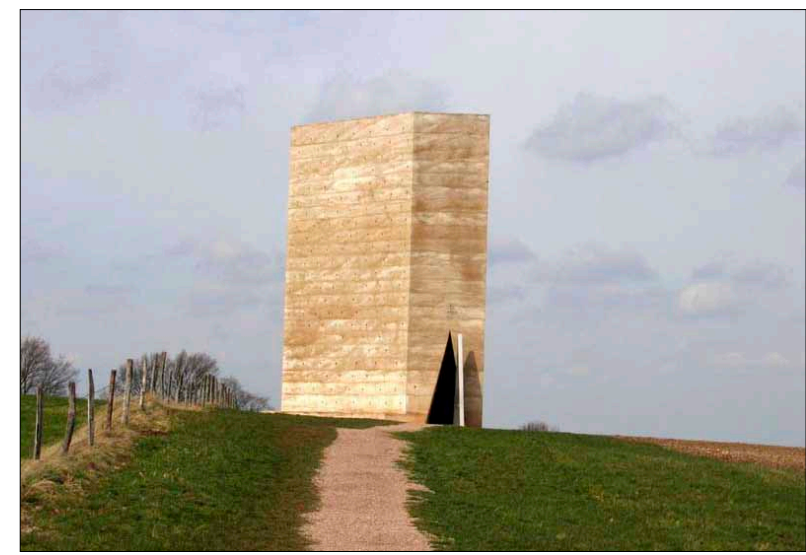

Panašios stilistikos sakralinès architektūros pavyzdžių Lietuvoje stinga, nors bandymų tokią erdvę kurti buvo. $2007 \mathrm{~m}$. surengtame Pašilaičiu bažnyčios ir parapijos namų idejjos konkurse nugalèję architektai Donaldas Trainauskas ir Darius Baliukevičius idejjiniame projekte numate iš monolitinių betono konstrukcijų suformuotą bažnyčios pastatą (6 pav.). Masyvus betono gretasienis komisiją sužavejjo lakoniškumu ir simboliškai ịprasminta pravirų durų idejja fasade. Tokia meninè idejja turètų skatinti įžengti pasauliečius ì sakralinę erdvę. Architektūros kokybę liudija harmoningos pastato proporcijos, kompozicinis integralumas i aplinką. Tačiau laikas parodè, kad tokio pobūdžio sakralinė architektūra sunkiai skinasi kelią ị mūsų visuomenę, dvasininkams atmetus šị laimèjusị projektą, buvo pakviestas kitas architektas kurti alternatyvaus, visiškai kitokios išraiškos projekto.

Jau minètame Pašilaičių bažnyčios ir parapijos namų idejos konkurse išsiskyrè ir architektès Andrès Baldišiūtės kartu su kūrybine grupe parengtas bažnyčios projektas (7 pav.). Suprojektuotas bažnyčios pastatas išsiskiria vientisa briaunota forma, o fasadų kompozici-
5 pav. Bruder Klaus koplyčia, Mechernichas, Vokietija (archit. P. Zumthor, $2007 \mathrm{~m}$.)

Fig. 5. Bruder Klaus Chapel, Mechernich, Germany (architect P. Zumthor, 2007)

joje vyrauja trikampių formų motyvai. Trikampis, kaip geometrinis simbolis, užkoduotas tiek liturginès erdvès planinèje formoje, tiek ị bendrą tūrị integruotame šventoriuje. Pastarojo projektinis sprendimas ypač inovatyvus, bažnyčios pastato ir šventoriaus erdvès suliejimas i bendrą formą suteikia jam jaukumo ir kameriškumo savybių. Bendra architektūrinè formų kalba grakšti ir santūri, baltos spalvos naudojimas šio projekto sprendiniuose prideda papildomų užuominų i i šviesos, tvarkos ir harmonijos simboliškumą.

Šiuolaikinè bažnyčių architektūra neretai kritikuojama dèl sakralinių simbolių stokos, dailès kūrinių integravimo interjere tradicijos nykimo. Tai ypač taikoma minimalizmo srovei priskirtiniems pastatams. Tačiau labiau ịsigilinus ị vieno ịtakingiausių XX a. Katalikų Bažnyčios teologijos korifejjų K. Rahnerio požiūrị i sakralumą, galima ịsitikinti, kad bažnyčios pastatą galima suvokti ir kitaip. Naujosios liturgijos samprata bei imanentiško Dievo pažinimo mokymas leidžia stebètojui regimą simbolį pakeisti i juslèmis patiriamą sakralumo išgyvenimą. Erdvè ir šviesa - pagrindiniai tokio pojūčio stimuliatoriai, simbolinè šviesos kaip substancijos 

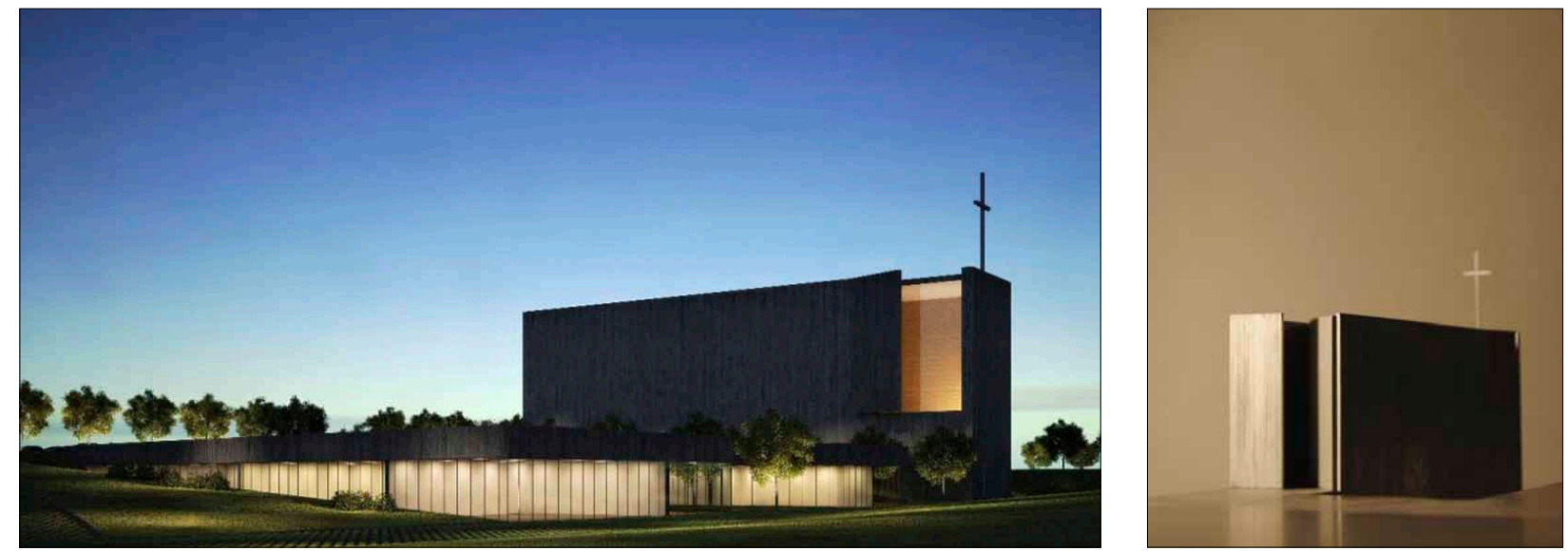

6 pav. Pašilaičių bažnyčios ir parapijos namų projektas Vilniuje (archit. D. Trainauskas, D. Baliukevičius, 2007 m.) Fig. 6. Competition project of the church in Pašilaičiai, Vilnius (architects D. Trainauskas, D. Baliukevičius, 2007)
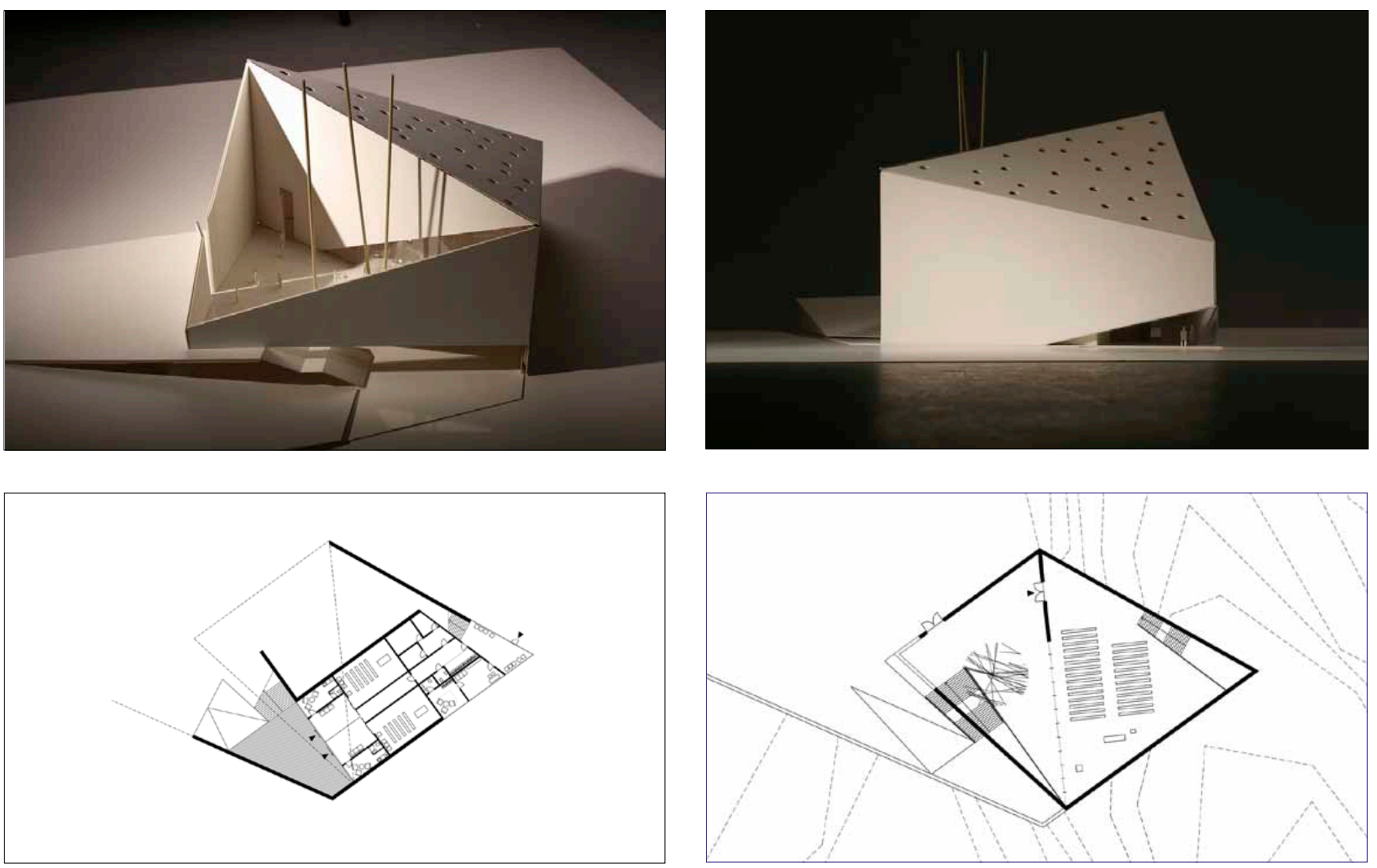

7 pav. Pašilaičių bažnyčios ir parapijos namų projektas Vilniuje (archit. A. Baldišiūtė, A. Neniškis ir kiti, 2007 m.) Fig. 7. Competition project of the church in Pašilaičiai, Vilnius (architects A. Baldišiūtè, A. Neniškis et al., 2007)

reikšmè krikščionybėje labai aiški - Šviesa = Žodis, taip skelbiama Jono evangelijos prologe. Todèl tokios architektūros simbolių kalba reikšminga ne pačių simbolių gausa ar ịvairove, bet jų ịprasminimo grynumu ir prasmès gilumu.

\section{Išvados}

1. Išanalizavus Hanso Urso von Balthasaro teologijos kertinius bruožus, išryškejjo, kad jo propaguojamos vertybės bei Dievo samprata yra ryškus Bažnyčios istorinio paveldo, kurị sudaro meno ir teologijos sintezé, atspindys. Tampa akivaizdu, jog bažnyčios pastatas Balthasarui simbolizuoja keliavimo į tikèjimą ir Dievo pažinimą priemonę, kartu ir regimąji dangiškųjų tiesų reprezentavimą. Kokybiniai kri-

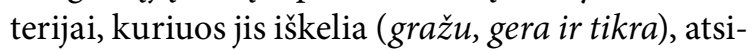
spindi bažnyčių altorių, tabernakulių puošyboje ar kituose sakralinès dailès kūriniuose.

2. Apibendrinant estetinių, simbolinių kriterijų reikšmę Katalikų Bažnyčios mokyme, pastebètina, jog H. U. Balthasaras buvo vienas iš aktyviausių regi- 
mąji groži iškeliančių teoretikų. Jis Dievą tiesiogiai siejo su grožiu, o žemiškajji groži traktavo kaip dangiškojo grožio atspindị. Todèl vertinant šiuolaikinę sakralinę architektūrą, y pač sukurtą brutalizmo ar minimalizmo stiliumi, neretai iš šiuolaikinių dvasininkų pasigirsta kritika tokių pastatų atžvilgiu, mat juose pasigendama Balthasaro iškeltų sakralumo, sakralaus grožio kanonų.

3. Žvelgiant ị kai kuriuos šiuolaikinių bažnyčių ar koplyčiu pastatus, juose išryškèja Karlo Rahnerio teologijos atspindžiai. Raiškiausiai jie pastebimi šiuolaikinių minimalizmo srovei priskiriamų bažnyčių architektūroje, kur žiūrovo dėmesys sutelkiamas į aktyvų dalyvavimą liturgijoje. Žmogus tokios architektūros apsuptyje nèra vien tik stebètojas, bet veikiau dalyvis. Sakralumo ir transcendencijos pojūtis yra kuriamas įtaigiai modeliuojant natūralią šviesą erdveje. Svarbu pabrèžti, jog minimalizmo stiliumi sukurta sakralinė architektūra nesistengia paneigti ankstesnių laikotarpių meninès kalbos, tiesiog kitomis meninèmis priemonemis perteikiamos, išryškinamos kitos ne mažiau aktualios Katalikų Bažnyčios mokymo tiesos. Sakraliniai simboliai tokiose šventovèse reiškiasi itin subtiliai, išlaikant kuklumą, asketiškumą, nesiekiant dominuoti ar kaustyti žiūrovo dèmesį vienoje vietoje.

4. Daugelyje šiuolaikinių minimalizmo srovès sakralinių pastatų raiškiai atsiskleidžia ikonoklazmo epochos idèjos, jos būdingos ir K. Rahnerio teologijai. Todèl nesunku issitikinti, jog erdvès sakralumas tokiose šventovèse kuriamas ne pažodiniais vaizdiniais ar įmantria puošyba, bet labiau per formų darną, šviesos ir monumentalių paviršių žaismą, aktyvų liturgijos šventimą, kuris pats savaime yra visos tikinčiųjų santalkos pagrindas. Akivaizdu, kad Rahnerio ịsitikinimas apie Dievo buvimą čia ir dabar, Jo pasiekiamumą kiekvienam, atsižvelgiant i tikinčiojo tobulejimą, formuoja prielaidas kitokiai, imanentiškesnei architektūrai sukurti. Todèl ir sakralinè erdvè, remiantis Rahnerio teologijos samprata, yra suvokiama kaip meditatyvinè erdve asmeniniam ar bendruomeniniam ryšiui su Dievu išgyventi.

\section{Literatūros sąrašas}

Cirlot, J. E. 2002. A dictionary of symols. Mineola: Dover Publications. ISBN 0-486-42523-1.

Christopherson, D. F. 2004. A place of encounter. Minneapolis: Augsburg Fortress. 49, 50 p. 55ISBN 0-8066-5107-5.

Demetrescu, C. 2000. Symbols in sacred architecture and iconography. The Institute for Sacred Architecture [interaktyvus], [žiūrèta 2011 balandžio 14 d.]. Prieiga per internetą: http:// www.sacredarchitecture.org/articles/symbols_in_sacred_ architecture_and_iconongraphy/
Hoffman, D. 2010. Seeking the sacred. Kent: The Kent State University Press, 6-7. ISBN 978-1-60635-047-8.

Jung, C. G. 1968. Man and his symbols. London: Aldus Books. 4 p. ISBN: 0-440-35183-9.

Lawlor, A. 1994. The temple in the house. New York: Tarcher/ Putnam Book. 145, 146 p. ISBN 0-87477-777-1.

Nichols, A. 2011. A key to Balthasar: Hans Urs von Balthasar on beauty, goodness, and truth. London: Baker Academics. 1 p. ISBN 978-0-8010-3974-4.

Paškus, A. 2002. Žvilgsnis ị pasauliežiūrinę aplinka, šventovę, save. Kaunas: Lietuvos Katechetikos Centro leidykla. 113 p. ISBN 9955-494-04-2

Schloeder, S. 1998. Architecture in communion. San Francisco: Ignatius. 29 p. ISBN 0-98870-631-9.

Stice, R. 2012. Living stone: the beauty of the liturgical altar. The Institute for Sacred Architecture [interaktyvus], [žiūrèta 2014 birželio 30 d.]. Prieiga per internetą: http://www. sacredarchitecture.org/articles/living_stone_the_beauty_ of_the_liturgical_altar/

Vosko, R. 2006. God's House is our house. Minnesota: Liturgical Press. 33 p. ISBN -13: 978-0-8146-3014-3.

\section{SYMBOLISM OF SACRED ARCHITECTURE IN THEOLOGY BY H. U. VON BALTHASAR AND K. RAHNER}

\section{Krūgelis}

Abstract. Closely tied to a particular religion, sacred architecture has always been hidden behind the veil of mystery and enigma. A wide variety of sacred symbols used in church architecture are little explored. In art criticism, symbols are often seen as visible and associative images that have a meaning of their own. Sacred architectural symbolism of the twentieth century has faced significant changes. The question is: why do new churches built in the minimalist style lack visible iconographic religious symbols and signs? Is the post-modern secular art to blame for the absence of artistic iconography? With the help of the interdisciplinary research, this article aims to discuss a possible impact of theological currents on contemporary church architecture. In addition, it compares the shift in the concept of a church as a building of worship after the Second Vatican Council. Finally, this article analyses examples of church architecture that emerged as a result of interaction between these processes.

Keywords: sacred space, symbol, church, architecture, theology, minimalism.

\section{LINAS KRŪGELIS}

Assoc. Professor, Department of Design, Vilnius Gediminas Technical University, Sauletekio al. 11, LT-2040 Vilnius, Lithuania. E-mail:linnarri@yahoo.com

$\mathrm{PhD}$ of Humanities, Assoc. Professor at Vilnius Gediminas Technical University. Research interests: architecture and design. 